\title{
Antimicrobial resistance profiles of Salmonella serovars isolated from dressed chicken meat at slaughter in Kaduna, Nigeria
}

\author{
Michael Agbaje ${ }^{1 *}$ Antonia Anna Lettini ${ }^{2}$ Olufemi Ernest Ojo \\ Alessandra Longo ${ }^{2}$ Elisa Marafin ${ }^{2}$ Keti Antonello ${ }^{2}$ \\ Paola Zavagnin ${ }^{2}$ Babafela Babalola Oluwasile ${ }^{1}$ \\ Ezekiel O. Omoshaba ${ }^{1}$ Morenike Atinuke Dipeolu ${ }^{1}$
}

\begin{abstract}
Keywords
Salmonella, resistance to antibiotic, chicken meat, slaughtering, Nigeria
\end{abstract}

\footnotetext{
Submitted: 14 December 2017

Accepted: 4 September 2019

Published: 15 November 2019

DOI: $10.19182 /$ remvt.31484
}

\begin{abstract}
Summary
Invasive non-typhoidal salmonellosis characterized by gastroenteritis and bacteremia is endemic in sub-Sahara Africa. Most infections are foodborne with animals serving as asymptomatic carriers. We investigated Salmonella serovars and associated resistance genes in chicken meat using culture, minimum inhibitory concentrations and PCR amplification of resistance genes. Of 100 samples examined, $28(28 \%)$ were Salmonella positive and spread across six serovars: Haifa (71.4\%), Chomedey (7.1\%), Saintpaul (7.1\%), Kainji (7.1\%), Derby (3.6\%), and Blockley (3.6\%). Antimicrobial resistance was observed to ciprofloxacin $(85.7 \%)$, nalidixic acid $(75.0 \%)$, sulfamethoxazole $(67.8 \%)$, tetracycline $(89.3 \%)$, trimethoprim (42.9\%), gentamicin (35.7\%), streptomycin $(32.1 \%)$, ampicillin $(10.7 \%)$, chloramphenicol $(10.7 \%)$, kanamycin $(7.1 \%)$ and florfenicol $(3.6 \%)$. All isolates were susceptible to cefotaxime, ceftazidime and colistin, whereas $19(67.9 \%)$ showed multidrug resistance to at least three antimicrobials. The predominant resistance type was Cip-Gen-Nal-Smx-Tet-Tmp detected in six $(21 \%)$ isolates. Multidrug resistance of Salmonella serovars was high in the sampled chicken meat with resistance most observed against ciprofloxacin. This suggests possible horizontal transfer of plasmid-mediated quinolone resistance genes, which may compromise the clinical use of fluoroquinolones. Thus, improved hygiene and provision of adequate facilities at meat processing centers could help limit meat contamination and foodborne transmission of multiresistant non-typhoidal Salmonella serovars from chickens to humans.
\end{abstract}

- How to quote this article: Agbaje M., Lettini A.A., Ojo O.E., Longo A., Marafin E., Antonello K., Zavagnin P., Oluwasile B.B., Omoshaba E.O., Dipeolu M.A., 2019. Antimicrobial resistance profiles of Salmonella serovars isolated from dressed chicken meat at slaughter in Kaduna, Nigeria. Rev. Elev. Med. Vet. Pays Trop., 72 (4): 173-179, doi: 10.19182/remvt.31484

\section{INTRODUCTION}

Salmonella is an enteric bacterial pathogen of the family Enterobacteriaceae and has the potential to invade tissue and cause bacteremia (de Jong et al., 2012). Globally, Salmonella serovars are among the leading cause of foodborne gastroenteritis and constitute health and socioeconomic burdens in both developed and developing countries. Non-typhoidal Salmonella enterica causes an annual estimate of 93.8

\footnotetext{
1. College of Veterinary Medicine, Federal University of Agriculture, PMB 2240, Abeokuta, Nigeria.

2. Istituto Zooprofilattico Sperimentale delle Venezie, National and OIE Reference Laboratory for Salmonellosis, Legnaro, Italy.

* Corresponding author

Tel.: +234 70157440 22; Email: mikeagbaje@gmail.com
}

million cases of gastroenteritis and 155,000 deaths worldwide, with over $85 \%$ of Salmonella gastroenteritis attributed to foodborne transmission (Majowicz et al., 2010). Food-producing animals have been implicated as major reservoirs and sources of zoonotic transmission of non-typhoidal salmonellosis (Kagambèga et al., 2013). In particular, poultry and poultry products play significant roles in the transmission of salmonellosis to humans. Apparently, healthy chickens may harbor non-typhoidal zoonotic S. enterica serovars in their gastrointestinal tracts, which are transmitted to humans through contact with carrier birds, fecescontaminated environment and consumption of contaminated food and water (Kagambèga et al., 2011; 2013).

In developing countries, cases of salmonellosis are often misdiagnosed because of inadequate laboratory investigations (Feasey et al., 2012). Moreover, unhygienic practices in food processing and in distribution chains, low-level awareness of non-typhoidal salmonellosis, malnutrition and concurrent infections may contribute to spread and severity of 
foodborne infections. Self-medication, delayed or lack of access to good health care, inappropriate prescriptions and prevailing cultural practices are additional factors that may contribute to complications, widespread dissemination, increased morbidity and case fatality of Salmonella gastroenteritis (Morpeth et al., 2009). Generally, the incidence of foodborne infection in developing countries is grossly underestimated because of poor record keeping, inadequate disease reporting and lack of coordinated monitoring and surveillance of important foodborne pathogens.

The increasing incidence of antimicrobial resistance by pathogenic and commensal bacteria is of public health concern. In sub-Saharan Africa, antimicrobial chemotherapy is an integral part of the management of invasive non-typhoidal Salmonella infections (Feasey et al., 2012). However, widespread acquisition and dissemination of antimicrobial resistance traits are continuously narrowing the antimicrobial therapeutic options available for the treatment of bacterial infections. Antimicrobial-resistant Salmonella spp. have been isolated from different foods of animal origin around the world (Garedew et al., 2015; Löfström et al., 2015; Saravanan et al., 2015). Extensive use of antimicrobial agents in animal production is common and selects for multidrug resistant (MDR) pathogens (Marshall and Levy, 2011; Oluwasile et al., 2014). Fluoroquinolones are broad-spectrum antimicrobials effective in the treatment of a wide variety of clinical and veterinary infections, particularly for life-threatening salmonellosis treatment.

Quinolone resistance in Salmonella is mainly attributed to point mutations in chromosomal genes encoding gyrase subunits $\mathrm{A}($ gyrA $)$ and B $(\operatorname{gyr} B)$, and topoisomerase subunits $\mathrm{C}$ (parC) and $\mathrm{E}$ (parE) (Hopkins et al., 2005). The fluoroquinolone resistance phenotype might be further modulated with the appearance of several plasmid-mediated quinolone resistance mechanisms (PMQR) (Luo et al., 2011; Wasyl et al., 2014) encoded by qnrA, qnrB, qnrS, qepA genes.

Factors responsible for the endemicity of non-typhoidal Salmonella infections in Africa are poorly understood (Morpeth et al., 2009). There is a dearth of information on the dynamics of Salmonella serovars and their antimicrobial resistance properties in livestock and food of animal origin. To prevent the continuous spread of antimicrobial resistance and zoonotic transmission of foodborne pathogens from animals to humans, there is a need for regular monitoring and reporting of resistant bacteria in food of animal origin. The present study investigated the occurrence of Salmonella serovars as well as their phenotypic and genotypic antimicrobial resistance properties in freshly dressed chicken meat in Kaduna in Northern Nigeria.

\section{MATERIALS AND METHODS}

\section{Sample collection}

One hundred neck skin samples were collected from freshly dressed chicken meat sold to consumers at two chicken processing facilities in Kaduna, capital of Kaduna State, Nigeria. Neck skin sampling was selected in this study since it provides higher Salmonella yields than whole carcass rinse and other skin parts (Diezhang et al., 2014). Fifty samples were collected from each facility, and sampling was carried out three times daily (morning, afternoon and evening) for two weeks in March 2012. In each center, one and sometimes two samples per visit were collected from different processors selling dressed chickens. Samples were collected in pre-labeled sample bags and preserved with ice pack in sterile containers before transport to the laboratory for microbiological analysis.

\section{Isolation and presumptive identification of Salmonella}

Salmonella isolation was performed according to ISO 6579 standard (2002) with minor modifications. In particular, each neck sample (10 g) was pre-enriched after thorough homogenization in $90 \mathrm{ml}$ of sterile buffered peptone water (BPW, Oxoid CM0509, UK), then incubated at $37^{\circ} \mathrm{C}$ for $18-24$ hours. From the BPW culture, $0.1 \mathrm{ml}$ was transferred into $9.9 \mathrm{ml}$ of modified semi-solid Rapport-Vassiliadis (MSRV) selective enrichment broth (Oxoid CM0910) supplemented with novobiocin (Oxoid SR0161), then incubated at $42^{\circ} \mathrm{C}$ for $24-48$ hours. Afterwards, MSRV was observed for the typical migration pattern of Salmonella enterica ( $\geq 2.0 \mathrm{~mm}$ migration) every 24 hours until 72 hours. A loopful of observable bacterial spread was taken from the periphery of MSRV medium and streaked simultaneously onto plates of brilliant green agar (BGA, Oxoid CM0263) supplemented with sulphamandelate (Oxoid SR0087) and onto xylose lysine desoxycholate agar (XLD, Oxoid). The inoculated plates were incubated at $37^{\circ} \mathrm{C}$ for $18-24$ hours, then examined for bacterial colonies. Typical Salmonella colonies were picked and subjected to biochemical and serological tests.

\section{Serotyping of Salmonella isolates}

Presumptive Salmonella isolates were shipped to the Office International des Epizooties (OIE) Reference Laboratory for Salmonella, Istituto Zooprofilattico Sperimentale delle Venezie (IZSVe, Italy). All strains were serotyped by agglutination tests with specific $\mathrm{O}$ and $\mathrm{H}$ antisera and classified according to Kauffman-White's scheme as previously described (Grimont and Weill, 2007).

\section{Phenotypic antimicrobial susceptibility testing}

Susceptibility to 14 antimicrobials was carried out to determine the minimum inhibitory concentrations by means of broth microdilution following the Clinical and Laboratory Standards Institute guidelines (CLSI, 2009). The CMV2AGNF (sensititre, Trek Diagnostic Systems, USA) susceptibility plates of the National Antimicrobial Monitoring System containing 14 antimicrobials was used. The antimicrobials tested were ampicillin, cefotaxime, ceftazidime, chloramphenicol, ciprofloxacin, colistin, florfenicol, gentamicin, kanamycin, nalidixic acid, streptomycin, sulfamethoxazole, tetracycline, and trimethoprim. The breakpoints used for sulfamethoxazole and kanamycin were CLSI (2009) breakpoints, whereas for other antimicrobials, the European Committee on Antimicrobial Susceptibility Testing (EUCAST) epidemiological cut-off was used (Aarestrup and McDermott, 2007; EUCAST, 2012). Escherichia coli (ATCC 25922) was used as the quality control strain.

\section{Determination of antimicrobial resistance genes}

DNA templates used for PCR were prepared by boiling as described by Barco et al. (2011). Molecular characterization of genetic antimicrobial resistance determinants in all isolates was undertaken by PCR amplification according to Beutlich et al. (2011). The isolates were analyzed for the presence of resistance genes corresponding to their resistance phenotypes. The resistance-associated genes investigated included those encoding resistance to beta-lactam antibiotics $\left(\right.$ bla $_{\mathrm{PSEl}}$, bla $_{\mathrm{TEM1}}$ like, $\left.b l a_{\text {OXA1-like }}\right)$, chloramphenicol and florfenicol (catAl, cmlA, floR), fluoroquinolones (gyrA, qnrA, qnrB, qnrS, qepA), gentamicin [aacC2, aacC4, aac(3)-Ie (aacC5), aadB, armA], kanamycin [aphA1, aphA2, aac(6)-1b], streptomycin (aadAl-like, strA, strB), sulfamethoxazole (sull, sul2, sul3), tetracycline $[\operatorname{tet}(\mathrm{A}), \operatorname{tet}(\mathrm{B}), \operatorname{tet}(\mathrm{G})]$, and trimethoprim (dfrAl-like, $d f r A 5-14, d f r A 7-17, d f r A 12)$. In particular, PCR amplification of gyrA gene and sequencing of purified amplicons were performed on both nucleotide strands to detect substitutions using ABI 100 DNA sequencer (Applied Biosystems, USA) as previously reported (Capoor et al., 2009). In each case, the $g y r A$ sequence obtained was compared with wild-type sequences (GenBank accession number AE006468.1).

\section{RESULTS}

\section{Prevalence of Salmonella serovars in chicken meat}

Culture and serology confirmed almost one third $(28 \%, 28 / 100)$ of the samples as Salmonella positive; they were spread across six serovars: 
$S$. Haifa, $S$. Chomedey, $S$. Saintpaul, $S$. Derby, $S$. Blockley and $S$. Kainji (Table I).

\section{Phenotypic antimicrobial resistance of $\mathrm{S}$. isolates}

The highest antimicrobial resistance was to ciprofloxacin $(85.7 \%$, 24/28), followed by nalidixic acid (75\%), sulfamethoxazole (67.8\%) and tetracycline $(89.3 \%$ ) (Table I). About half of Salmonella isolates showed resistance to trimethoprim, gentamicin and streptomycin, whereas small numbers of isolates were resistant to ampicillin, chloramphenicol, kanamycin and florfenicol. All isolates were susceptible to cefotaxime, ceftazidime and colistin, whereas the two representatives of $S$. Kainji were susceptible to all tested antimicrobial agents (Table I). Of the 26 resistant isolates, nineteen (67.9\%) showed multidrug resistance to at least three different classes of antimicrobials. The most prevalent resistance type (R-type) was Cip-Gen-Nal-Smx-Tet-Tmp observed in six (21\%) isolates, followed by Cip-Nal-Tet in four (14\%) isolates (Table II).

\section{Antimicrobial resistance genes in Salmonella isolates}

The $b l a_{\mathrm{TEM}}$ gene coding for beta-lactam resistance was detected in all three ampicillin-resistant isolates (Table I). The floR gene encoded resistance to chloramphenicol and florfenicol in one isolate. Two chloramphenicol-resistant isolates carried $\mathrm{cmlA}$ gene. Streptomycin was mainly encoded by $s t r B$ (6 isolates) and/or strA (1 isolate) genes except for two isolates that showed only aadl-like gene. Gentamicin resistance was mediated by aacC2 (7/10 resistant isolates) and acc(3)-le (3/10 resistant strains) genes. Sulfamethoxazole resistance was mostly associated with sull (15/19), however, sul2 (2/19) and sul3 (2/19) were also detected. Tetracycline resistance was uniquely encoded by tet(A) in 25 isolates. Trimethoprim resistance was uniquely encoded by $d f r A 5-14$ (12 isolates). Substitutions in the codons of gyrA were responsible for fluoroquinolone resistance in 21 isolates. Sequence analysis revealed mutation of amino acid at position 83 (TCC $\rightarrow$ TAC, Ser83 $\rightarrow$ Tyr) in 17 isolates and (TCC $\rightarrow$ TTC, Ser83 $\rightarrow$ Phe) in four isolates. Three fluoroquinolone-resistant isolates with similar R-type (Cip-Gen-Nal-SmxStr-Tet-Tmp) had double point mutations in their gyrA gene. The first mutation occurred at position 83 (TCC $\rightarrow$ TTC, Ser83 $\rightarrow$ Phe), the second at position $87(\mathrm{GAC} \rightarrow \mathrm{GGC}$, Asp87 $\rightarrow$ Gly). Three (10.7\%) of the Salmonella isolates carried a $q n r$ gene. These isolates were characterized by a reduced level of fluoroquinolone resistance $(0.5-1 \mathrm{mg} / \mathrm{l})$ and no simultaneous chromosomal mutations occurred in gyrase or topoisomerase. Two isolates ( $S$. Chomedey) carried $q n r B$ gene and one isolate $(S$. Derby) $q n r S$ gene.

\section{DISCUSSION}

The results showed high contamination of poultry meat during processing with potentially zoonotic non-typhoidal Salmonella serovars. The serovars detected have been associated throughout the world with foodborne infections in humans. For instance, Kaibu et al. (2005) report fatal cases of food intoxication by Salmonella Haifa in an older person and in a child. $S$. Derby was reported in an outbreak of foodborne

Table I

Distribution of resistant isolates and resistance genes among Salmonella serovars isolated from fresh chicken meat in Kaduna, Nigeria

\begin{tabular}{|c|c|c|c|c|c|c|c|c|}
\hline \multirow[t]{2}{*}{ Antimicrobial agent } & \multirow{2}{*}{$\begin{array}{l}\text { Resistance } \\
\text { gene }\end{array}$} & \multicolumn{5}{|c|}{ Salmonella serovars* } & \multirow{2}{*}{$\begin{array}{c}\text { Total } \\
(\mathrm{n}=28)\end{array}$} & \multirow[t]{2}{*}{$\%(95 \% \mathrm{Cl})$} \\
\hline & & $\begin{array}{l}\text { S. Haifa } \\
(\mathrm{n}=20)\end{array}$ & $\begin{array}{l}\text { S. Derby } \\
(n=1)\end{array}$ & $\begin{array}{l}\text { S. Chomedey } \\
(n=2)\end{array}$ & $\begin{array}{l}\text { S. Blockley } \\
(n=1)\end{array}$ & $\begin{array}{l}\text { S. Saintpaul } \\
(n=2)\end{array}$ & & \\
\hline Ampicillin & bla $a_{\mathrm{TEM}}$ & 1 & - & - & - & 2 & 3 & $10.7(2.9-28.0)$ \\
\hline Cefotaxime & - & - & - & - & - & - & - & - \\
\hline Ceftazidime & - & - & - & - & - & - & - & - \\
\hline Chloramphenicol & CmIA1 & - & - & - & - & 2 & 2 & $7.1(0.9-23.7)$ \\
\hline $\begin{array}{l}\text { Chloramphenicol/ } \\
\text { florfenicol }\end{array}$ & floR & 1 & - & - & - & & 1 & $3.6(0.0-19.2)$ \\
\hline Colistin & - & - & - & - & - & - & - & - \\
\hline $\begin{array}{l}\text { Fluoroquinolone } \\
\text { (ciprofloxacin) }\end{array}$ & gyrA mutation & 20 & - & - & 1 & - & 21 & $75(56.4-87.6)$ \\
\hline $\begin{array}{l}\text { Fluoroquinolone } \\
\text { (ciprofloxacin) }\end{array}$ & $q n r B$ & - & - & 2 & - & - & 2 & $7.1(0.9-23.7)$ \\
\hline $\begin{array}{l}\text { Fluoroquinolone } \\
\text { (ciprofloxacin) }\end{array}$ & $q n r S$ & - & 1 & - & - & - & 1 & $3.6(0.0-19.2)$ \\
\hline Gentamicin & aасC2 & 7 & - & - & - & - & 7 & 25 (12.4-43.6) \\
\hline Gentamicin & aаc(3)-le & 3 & - & - & - & - & 3 & $10.7(2.9-28.0)$ \\
\hline Kanamycin & aphA1 & - & - & - & 1 & 1 & 2 & $7.1(0.9-23.7)$ \\
\hline Nalidixic acid & - & 20 & - & - & 1 & - & 21 & 75 (56.4-87.6) \\
\hline Streptomycin & strA & 1 & - & - & - & - & 1 & $3.6(0.0-19.2)$ \\
\hline Streptomycin & $s t r B$ & 3 & - & 2 & 1 & - & 6 & $21.4(9.9-39.9)$ \\
\hline Streptomycin & aad-1like & - & - & - & - & 2 & 2 & $7.1(0.9-23.7)$ \\
\hline Sulfamethoxazole & sul1 & 15 & - & - & - & - & 15 & $53.6(35.8-70.5)$ \\
\hline Sulfamethoxazole & sul2 & - & - & 2 & - & - & 2 & $7.1(0.9-23.7)$ \\
\hline Sulfamethoxazole & sul3 & - & - & - & - & 2 & 2 & $7.1(0.9-23.7)$ \\
\hline Tetracycline & tet(A) & 19 & 1 & 2 & 1 & 2 & 25 & $89.3(72.0-97.1)$ \\
\hline Trimethoprim & dfrA5-14 & 12 & - & - & - & - & 12 & $42.9(26.5-61.0)$ \\
\hline
\end{tabular}

No resistant isolates were found for $S$. Kainji $(\mathrm{n}=2)$ 


\section{Table II}

Phenotypic and genotypic resistance patterns of Salmonella serovars isolated from fresh chicken meat in Kaduna, Nigeria

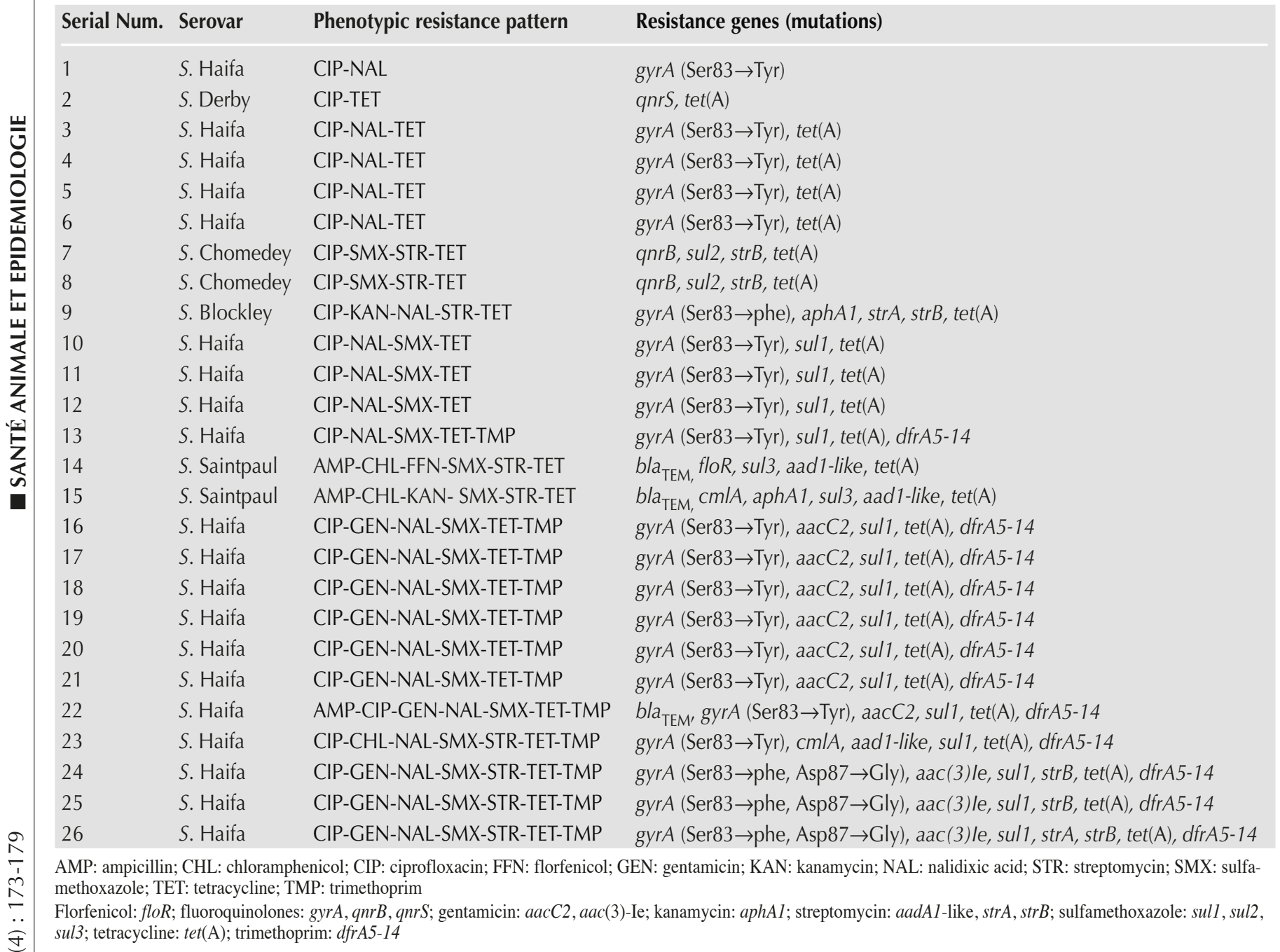

salmonellosis following the consumption of grilled meat in Fukuka City in Japan (Ebuchi et al., 2006). S. Saintpaul was responsible for a large foodborne outbreak of salmonellosis involving 1500 cases with $21 \%$ hospitalizations and two deaths in the United States (Barton et al., 2011). Gonose et al. (2012) reported S. Blockley as the etiology of foodborne illness characterized by diarrhea, stomach cramp and headaches in three adult males in South Africa.

The $28 \%$ overall prevalence rate of Salmonella observed in dressed chicken in our study was higher than those of $11 \%$ reported in the feces of on-farm chickens in Ibadan (Fashae et al., 2010), and of 2.3-5.2\% in feces and intestinal samples of chickens in Maiduguri, Nigeria (Raufu et al., 2009). Unhygienic processing including lack of proper separation of dirty and clean areas during evisceration in the slaughterhouse, unhygienic processors and equipment contributed to the contamination of carcasses during processing. In addition, the extent of colonization of the crop due to feed withdrawal during transportation and resting exposes carcasses to possible contamination (Ramirez et al., 1997). Salmonella contamination of the neck skin has been linked to colonization of the crop since this organ is more likely to be ruptured during processing than other parts of the gastrointestinal tract such as the ceca (Hargis et al., 1995). Finally, successful contamination of carcasses and slaughter lines may also depend on the toughness of the contaminating Salmonella strain, considering that such strains survive environmental stress usually associated with slaughterhouses (Olsen et al., 2003; Rasschaert et al., 2007).

$S$. Haifa was the predominant (71.4\%) serovar detected in the present study. Five other serovars were also detected suggesting that chicken meat may act as a vehicle for the transmission of diverse ranges of Salmonella serovars. Fashae et al. (2010) detected eight S. serovars (Virchow, Bredeney, Derby, Haifa, Havana, Muenster, Mbandaka and Onireke) in the feces of on-farm chickens in Ibadan, and $S$. Virchow accounted for $71 \%$ of all isolates. In Maiduguri, $S$. Hiduddify was the main $(95 \%)$ serovar isolated from chicken feces and tissues (Raufu et al., 2009). Differences in geographical location, sampling site and type may account for the observed disparities betwen these studies. Although the $S$. serovars detected in this study could originate from the intestinal content of chickens, they may have originated from extraneous sources including the persons involved in processing chicken meat.

Fluoroquinolones, especially ciprofloxacin, are the drugs of choice in the treatment of human salmonellosis (Akinyemi et al., 2007) and they are also used frequently in livestock medicine. Resistance to ciprofloxacin was found in over $85 \%$ of all isolates. Most fluoroquinolone resistance $(87.5 \%)$ was mediated by chromosomal mutations on $g y r A$ gene. Resistance mutations occurring on gyrA gene, corresponding to amino acid changes at Ser-83 (to Phe or Tyr) or at Asp-87 (to Gly), are the most frequently observed in fluoroquinolone resistant strains (Piddock, 
2002; Hopkins et al., 2005). In addition to these site mutations, there were occurrence and dissemination of $q n r$ genes in Salmonella isolates in this study, even though they were quite low (10.7\%). This suggests horizontal spread of resistance plasmid determinants in Kaduna State as reported by Fortini et al. (2011). However, it is notable that wide dissemination of PMQR genes mainly in commensal or pathogenic Gram-negative bacteria is mostly associated with defined successful plasmids which could be positively selected by other drugs because of the co-location of multiple resistance determinants (Fortini et al., 2011). In general, the acquisition of $\mathrm{PMQR}$ genes decreases susceptibility to fluoroquinolones and may accelerate selection of fluoroquinolone-resistant mutants (Martínez-Martínez et al., 2003; Rodríguez-Martínez et al., 2007). Given their transferability and the possibility that they may cause increases in resistance thereby affecting the clinical response to treatment, data on the occurrence of PMQR genes are important for the surveillance of quinolone resistance in humans and animals. In developing countries where poor facilities hamper accurate and timely diagnosis, antimicrobial agents are administered empirically for the treatment of suspected cases of salmonellosis without recourse to laboratory investigation. Resistance may complicate Salmonella infections as resistant strains are more likely to be associated with tissue invasion, severe illness and death (Helms et al., 2004).

In this study there was a high resistance to (fluoro)quinolones, sulfonamide and tetracycline, a moderate resistance to trimethoprim and aminoglycosides, and a low resistance to ampicillin and phenicol antimicrobials. This could be a reflection of the pattern of antimicrobial use in the poultry industry. Usage of any particular antimicrobial agent could exert selective pressure leading to the emergence, proliferation and spread of bacterium strains showing resistance to the antimicrobial agent. Previous studies have shown that fluoroquinolones, sulfonamides and tetracyclines are the most widely used antimicrobial agents in the Nigerian poultry industry (Ogunleye et al., 2008; Oluwasile et al., 2014). In our study resistance to tetracycline was found in five out of six serovars and was uniquely associated with tet(A) gene. Tetracycline is used as an additive in water and feed to improve performance, whereas ciprofloxacin is the ready choice for the treatment of bacterial infections and sometimes for prophylaxis (Oluwasile et al., 2014).

Although three serovar types (Haifa, Saintpaul and Chomedey) showed resistance to sulfamethoxazole, the resistance was mediated by different genes. The sull gene was responsible for resistance in all isolates belonging to serovar Haifa. In $S$. Chomedey, sulfamethoxazole resistance was due to sul2, whereas in S. Saintpaul it was due to sul3. Two isolates of $S$. Saintpaul possessed $\mathrm{cmlA}$, which accounted for resistance to chloramphenicol, whereas in $S$. Haifa resistance to chloramphenicol and its derivative (florfenicol) was mediated by floR. All gentamicin-resistant Salmonella isolates belonged to serovar Haifa and resistance was attributable mainly to a acC2 (seven isolates) but also to aac(3)-Ie (three isolates). Similarly, trimethoprim resistance was observed only in $S$. Haifa and was encoded solely by $d f r A 5-14$ gene. Two $S$. Saintpaul isolates and one $S$. Haifa showed resistance to ampicillin and possessed $b l a_{T E M}$ gene. Resistance to streptomycin was detected in nine isolates belonging to four different serovars. Three streptomycin-associated genes were detected: $s t r A$ and $s t r B$ in $S$. Haifa, strB in S. Chomedey and Blockley, and aadA-like in $S$. Saintpaul. The Salmonella isolates were completely susceptible to cefotaxime, ceftazidime and colistin. These drugs are not known to be used in poultry production. Susceptibility to cefotaxime and ceftazidime indicated that cephalosporins including highly important third and fourth generation antimicrobials will be very effective in the treatment of life-threatening and complicated salmonelloses in humans.

These findings are subject to at least two limitations. Firstly, these data were mainly collected from chickens originating from Kaduna State and other parts of Northern Nigeria which produce live chickens, and secondly, the relatively small sample size, which depended on budgetary constraints since whole chickens had to be purchased to allow for sampling. Notwithstanding these limitations, this study offers some insight into the circulating non-typhoidal Salmonella serovars and their antibiogram.

\section{CONCLUSION}

The study showed that chicken meat may contribute to the transmission of non-typhoidal Salmonella serovars in the area. In addition, the Salmonella observed might have been attributed to unhygienic handling during processing. This included observed poor personal hygiene among processors during processing as well as poor slaughterhouse sanitation due to inadequate infrastructure and unclean running water. Improved hygiene, provision of slaughter facilities, as well as adequate inspection at meat processing centers may limit meat contamination and reduce the risk of zoonotic transmission of non-typhoidal salmonellosis to humans. Furthermore, the study revealed circulation of $S$. serovars that are predominantly multidrug resistant. Preventive measures against misuse of antibiotics, including strict monitoring of antibiotics use both for prophylaxis and growth stimulation in poultry farms will mitigate antibiotic resistance development.

\section{Acknowledgments}

The authors appreciate the laboratory scientists in the Department of Veterinary Microbiology, College of Veterinary Medicine, Federal University of Agriculture, Abeokuta, Nigeria, and OIE Reference Laboratory for Salmonella, IZSVe, Legnaro, Italy. This project was partly supported by the International Livestock Research Institute (ILRI), Kenya.

\section{Author contributions statement}

MA, AAL, OEO, MAD designed and planned the study; MA, AL, $\mathrm{EM}, \mathrm{KA}, \mathrm{PZ}, \mathrm{BBO}, \mathrm{EOO}$ performed experiments and collected data; MA, AAL, OEO analyzed and interpreted data; MA, AAL, OEO, $\mathrm{BBO}, \mathrm{AL}, \mathrm{EM}, \mathrm{KA}, \mathrm{PZ}$, EOO drafted the first version of the manuscript; MA, AL, OEO, MAD critically reviewed the manuscript.

\section{REFERENCES}

Akinyemi K.O., Bamiro B.S., Coker A.O., 2007. Salmonellosis in Lagos, Nigeria: incidence of Plasmodium falciparum-associated co-infection, patterns of antimicrobial resistance, and emergence of reduced susceptibility to fluoroquinolones. J. Health Popul. Nutr., 25 (3): 351-358

Arestrup F., McDermott P., Kahlmeter G., 2007. Antimicrobial susceptibility testing - clinical break points and epidemiological cut-off values. Community Reference Laboratory for Antimicrobial Resistance, European Union, Newsl. 2, 3-5

Barco L., Lettini A.A., Ramon E., Longo A., Saccardin C., Pozza M.C.D., Ricci A., 2011. A rapid and sensitive method to identify and differentiate Salmonella enterica serotype Typhimurium and S. enterica serotype 4,[5],12:i:- by combining traditional serotyping and multiplex polymerase chain reaction. Foodborne Pathog. Dis., 8 (6): 741-743, doi:10.1089/fpd.2010.0776

Barton B.C., Mody K.R., Jungk J., Gaul L., Redd T.J., Chen S., Cosgrove S., et al., 2011. 2008 outbreak of Salmonella Saintpaul infections associated with raw produce. N. Engl. J. Med., 364 (10): 918-927, doi: 10.1056/NEJMoa1005741

Beutlich J., Jahn S., Malorny B., Hauser E., Huhn S., Schroeter A., Rodicioet R.M., et al., 2011. Antimicrobial resistance and virulence determinants in European Salmonella genomic island 1-positive Salmonella enterica isolates from different origins. Appl. Environ. Microbiol., 77 (16): 5655-5664, doi 10.1128/AEM.00425-11

Capoor R.M., Nair D., Walia S.N., Routela S.R., Grover S.S., Deb M., Aggarwal P., et al., 2009. Molecular analysis of high-level ciprofloxacin resistance in Salmonella enterica serovar Typhi and S. Paratyphi A: need to expand the QRDR region? Epidemiol. Infect., 137 (6): 871-878, doi: 10.1017/ S0950268808001076 
Clinical and Laboratory Standards Institute, 2009. Methods for dilution antimicrobial susceptibility tests for bacteria that grow aerobically, 8th edn. CLSI Wayne, PA, USA

De Jong H.K., Parry C.M., Van der Poll T., Wiersinga W.J., 2012. Host-pathogen interaction in invasive salmonellosis. PLoS Pathog., 8 (10): e1002933, doi: 10.1371/journal.ppat.1002933

Diezhang Wu., Alali Q.W., Harrison A.M., Hofacre L.C., 2014. Prevalence of Salmonella in neck skin and bone of chickens. J. Food Prot., 77 (7): 1193 1197, doi: 10.4315/0362-028X.JFP-14-006

Ebuchi S., Baba A., Uryu K., Hiwaki H., 2006. Two outbreaks caused by Salmonella Derby and $S$. Anatum at grilled-meat restaurants in Fukuoka City. Jpn. J. Infect Dis., 59 (6): 405-406

European Committee on Antimicrobial Susceptibility Testing, 2012. Definitions of clinical breakpoints and epidemiological cut-off values. EUCAST Development Laboratory, Sweden

Fashae K., Ogunsola F., Aarestrup F.M., Hendriksen R.S., Hendriksen R.S. 2010. Antimicrobial susceptibility and serovars of Salmonella from chickens and humans in Ibadan, Nigeria. J. Infect. Dev. Ctries., 4 (8): 484-494, doi: 10.3855/jidc.909

Feasey N.A., Dougan G., Kingsley R.A., Heyderman R.S., Gordon M.A., 2012. Invasive non-typhoidal Salmonella disease: an emerging and neglected tropical disease in Africa. Lancet, 379: 2489-2499, doi: 10.1016/S01406736(11)61752-2

Fortini D., Fashae K., Garcia-Fernandez A., Villa L., Carattoli A., 2011. Plasmid-mediated quinolone resistance and $\beta$-lactamases in Escherichia coli from healthy animals from Nigeria. J. Antimicrob. Chemother., 66 (6): 1269-1272, doi: 10.1093/jac/dkr085

Garedew L., Hagos Z., Addis Z., Tesfaye R., Zegeye B., 2015. Prevalence and antimicrobial susceptibility patterns of Salmonella isolates in association with hygienic status from butcher shops in Gondar town, Ethiopia. Antimicrob. Resist. Infect. Control., 4: 21, doi: 10.1186/s13756-015-0062-7

Gonose T., Smith M.A., Keddy H.K., Sooka A., Howell V., Jacobs A.C., Haffejee S., et al., 2012. Human infections due to Salmonella Blockley, a rare serotype in South Africa: a case report. BMC Res. Notes. 5 (1): 562, doi: 10.1186/1756-0500-5-562

Grimont P.A., Weill F.X., 2007. Antigenic formulae of the Salmonella serovars, 9th Edn. WHO Collaborating Centre for Reference and Research on Salmonella, Paris, France

Hargis B.M., Caldwell J.D., Brewer L.R., Corrier E.D., Deloach R.J., 1995. Evaluation of the chicken crop as a source of Salmonella contamination for broiler carcasses. Poult. Sci., 74: 1548-1552, doi: 10.3382/ps.0741548

Helms M., Simonsen J., Mølbak K., 2004. Quinolone resistance is associated with increased risk of invasive illness or death during infection with Salmonella serotype Typhimurium. J. Infect. Dis., 190 (9): 1652-1654, doi: $10.1086 / 424570$

Hopkins K.L., Davies R.H., Threlfall E.J., 2005. Mechanisms of quinolone resistance in Escherichia coli and Salmonella: recent developments. Int. J. Antimicrob. Agents, 25 (5): 358-373, doi: 10.1016/j.ijantimicag.2005.02.006

Kagambèga A., Haukka K., Siitonen A., Traore A.S., 2011. Prevalence of Salmonella enterica and the hygienic indicator Escherichia coli in raw meat at markets in Ouagadougou, Burkina Faso. J. Food Prot., 74 (9): 1547-1551, doi: 10.4315/0362-028X.JFP-11-124

Kagambèga A., Lienemann T., Aulu L., Traoré S.A., Barro N., Siitonen A., Haukka K., 2013. Prevalence and characterization of Salmonella enterica from the feces of cattle, poultry, swine and hedgehogs in Burkina Faso and their comparison to human Salmonella isolates. BMC Microbiol., 13 (1): 253, doi: 10.1186/1471-2180-13-253

\section{Résumé}

Agbaje M., Lettini A.A., Ojo O.E., Longo A., Marafin E., Antonello K., Zavagnin P., Oluwasile B.B., Omoshaba E.O., Dipeolu M.A. Profils de résistance antimicrobienne de sérotypes de salmonelles isolés à partir de viande de poulet apprêtée à l'abattoir à Kaduna, Nigeria

La salmonellose invasive non typhique, caractérisée par une gastro-entérite et une bactériémie, est endémique en Afrique subsaharienne. La plupart des infections sont d'origine alimentaire, les animaux servant de porteurs asymptomatiques. Nous
Kaibu H., Higashine H., lida K., Ueki S., Ehara H., 2005. A fatal food intoxication case due to Salmonella Haifa. Jpn. J. Infect. Dis., 58 (3): 192-193

Löfström C., Hintzmann A.S., Sørensen G., Baggesen D.L., 2015. Outbreak of Salmonella enterica serovar Typhimurium phage type DT41 in Danish poultry production. Vet. Microbiol., 178 (1): 167-172, doi: 10.1016/j.vetmic.2015.04.017

Luo Y., Li J., Meng Y., Ma Y., Hu C., Jin S., Zhang Q., et al., 2011. Joint effects of topoisomerase alterations and plasmid-mediated quinolone-resistant determinants in Salmonella enterica Typhimurium. Microb. Drug. Resist., 17 (1): 1-5, doi: 10.1089/mdr.2010.0074

Majowicz E.S., Musto J., Scallan E., Angulo J.F., Kirk M., O’Brien J.S., Jones F.T., et al., 2010. The global burden of nontyphoidal Salmonella gastroenteritis. Clin. Infect. Dis., 50 (6): 882-889, doi: 10.1086/650733

Marshall B.M., Levy, S.B., 2011. Food animals and antimicrobials: Impacts on human health. Clin. Microbiol. Rev., 24 (4): 718-733, doi: 10.1128/ CMR.00002-11

Martínez-Martínez L., Pascual A., García I., Tran J., Jacoby G.A., 2003. Interaction of plasmid and host quinolone resistance. J. Antimicrob. Chemother., 51 (4): 1037-1039, doi: 10.1093/jac/dkg157

Morpeth S.C., Ramadhani H.O., Crump J.A., 2009. Invasive non-Typhi Salmonella disease in Africa. Clin. Infect. Dis., 49 (4): 606-611, doi: 10.1086/603553

Ogunleye A.O., Oyekunle M.A., Sonibare A.O., 2008. Multidrug resistant Escherichia coli isolates of poultry origin. Vetrinarski Arhiv., 78 (6): 501-509

Olsen J.E., Brown J.D., Madsen M., Bisgaard M., 2003. Cross contamination on a broiler slaughterhouse line demonstrated by use of epidemiological markers. J. Appl. Microbiol., 94: 826-835, doi: 10.1046/j.13652672.2003.01911.x

Oluwasile B.B., Agbaje M., Ojo O.E., Dipeolu M.A., 2014. Antibiotic usage pattern in selected poultry farms in Ogun State. Sokoto J. Vet. Sci., 12 (1): 45-50, doi: 10.4314/sokjvs.v12i1.7

Piddock L.J.V., 2002. Fluoroquinolone resistance in Salmonella serovars isolated from humans and food animals. FEMS Microbiol. Rev., 26 (1): 3-16, doi: 10.1111/j.1574-6976.2002.tb00596.x

Ramirez G.A., Sarlin L.L., Caldwell J.D., Yezak Jr R.C., Hume E.M., Corrier E.D., Deloach R.J., et al., 1997. Effect of feed withdrawal on the incidence of Salmonella in the crops and ceca of market age broiler chickens. Poult. Sci., 76: 654-656, doi: 10.1093/ps/76.4.654

Rasschaert G., Houf K., De Zutter L., 2007. Impact of the slaughter line contamination on the presence of Salmonella on broiler carcasses. J. Appl. Microbiol., 103: 333-341, doi: 10.1111/j.1365-2672.2006.03248.x

Raufu I., Hendriksen R.S., Ameh J.A., Aarestrup F.M., 2009. Occurrence and characterization of Salmonella Hiduddify from chickens and poultry meat in Nigeria. Foodborne Pathog. Dis., 6 (4): 425-430, doi: 10.1089/ fpd.2008.0150

Rodríguez-Martínez J.M., Velasco C., García I., Cano M.E., Martínez-Martínez L., Pascual A., 2007. Mutant prevention concentrations of fluoroquinolones for Enterobacteriaceae expressing the plasmid-carried quinolone resistance determinant qnrA1. Antimicrob. Agents Chemother., 51 (6): 2236-2239, doi: 10.1128/AAC.01444-06

Saravanan S., Purushothaman V., Murthy K.G.R.T., Sukumar K., Srinivasan P., Gowthaman V., Balusamy M., et al., 2015. Molecular epidemiology of nontyphoidal Salmonella in poultry and poultry products in India: Implications for human health. Indian I. Med. Microbiol., 55 (3): 319-326, doi: 10.1007/ s12088-015-0530-z

Wasyl D., Hoszowski A., Zając M., 2014. Prevalence and characterisation of quinolone resistance mechanisms in Salmonella spp. Vet. Microbiol., 171 (34): 307-314, doi: 10.1016/j.vetmic.2014.01.040

\section{Resumen}

Agbaje M., Lettini A.A., Ojo O.E., Longo A., Marafin E., Antonello K., Zavagnin P., Oluwasile B.B., Omoshaba E.O., Dipeolu M.A. Perfiles de resistencia antimicrobiana a serovares de Salmonella aislados de carne de pollo en mataderos de Kaduna, Nigeria

La salmonelosis invasiva no tifoidea, caracterizada por gastroenteritis y bacteriemia es endémica en África subsahariana. La mayoría de las infecciones son de origen alimenticio, con animales actuando como portadores asintomáticos. Investigamos 
avons étudié les sérotypes de Salmonella et les gènes de résistance associés dans la viande de poulet à l'aide de cultures, de concentrations minimales inhibitrices et de l'amplification par PCR des gènes de résistance. Sur 100 échantillons examinés, 28 (28\%) étaient positifs pour Salmonella et répartis dans six sérotypes : Haïfa (71,4\%), Chomedey $(7,1 \%)$, Saintpaul $(7,1 \%)$, Kainji $(7,1 \%)$, Derby $(3,6 \%)$ et Blockley $(3,6 \%)$. Une résistance antimicrobienne à la ciprofloxacine $(85,7 \%)$, à I'acide nalidixique (75,0\%), au sulfaméthoxazole $(67,8 \%)$, à la tétracycline $(89,3 \%)$, au triméthoprime $(42,9 \%)$, à la gentamicine $(35,7 \%)$, à la streptomycine $(32,1 \%)$, à l'ampicilline $(10,7 \%)$, au chloramphenicol $(10,7 \%)$, à la kanamycine $(7,1 \%)$ et au florfenicol $(3,6 \%)$ a été observée. Tous les isolats ont été sensibles à la céfotaxime, à la ceftazidime et à la colistine ; 19 (67,9\%) ont présenté une multirésistance à au moins trois antimicrobiens. Le type de résistance prédominant était Cip-Gen-Nal-Smx-Tet-Tmp, détecté dans six isolats $(21 \%)$. La multirésistance des sérovars de Salmonella était élevée dans la viande de poulet échantillonnée, et la résistance la plus souvent observée était contre la ciprofloxacine. Cela suggère la possibilité $d^{\prime} u n$ transfert horizontal des gènes de résistance à la quinolone à médiation plasmidique, ce qui pourrait compromettre l'utilisation clinique des fluoroquinolones. Ainsi, l'amélioration de l'hygiène et la mise en place d'installations adaptées dans les centres de transformation de la viande pourraient contribuer à limiter la contamination de la viande et la transmission aux humains des sérotypes multirésistants non typhiques de Salmonella par la viande de poulets.

Mots-clés : Salmonella, résistance aux antibiotiques, viande de poulet, abattage d'animaux, Nigeria serovares de Salmonella y los genes de resistencia asociados en carne de pollo, mediante cultivo, concentraciones mínimas inhibitorias y amplificación de PCR de los genes de resistencia. De las 100 muestras examinadas, $28(28 \%)$ fueron positivas a Salmonella y se distribuyeron en seis serovares: Haifa $(71,4 \%)$, Chomedey $(7,1 \%)$, Saintpaul (7,1\%), Kainji $(7,1 \%)$, Derby $(3,6 \%)$, y Blockley $(3,6 \%)$. La resistencia antimicrobiana se observó a ciprofloxacina $(85,7 \%)$, ácido nalidíxico $(75,0 \%)$, sulfametoxazol $(67,8 \%)$, tetraciclina $(89,3 \%)$, trimetoprima $(42,9 \%)$, gentamicina $(35,7 \%)$, estreptomicina $(32,1 \%)$, ampicilina $(10,7 \%)$, cloranfenicol $(10,7 \%)$, kanamicina $(7,1 \%)$ y florfenicol $(3,6 \%)$. Todos los aislamientos fueron susceptibles a cefotaxima, ceftazidima y colistina, mientras que $19(67,9 \%)$ mostraron resistencia múltiple a por lo menos tres antimicrobianos. El tipo de resistencia predominante fue Cip-Gen-Nal-Smx-Tet-Tmp, detectado en seis $(21 \%)$ aislamientos. La resistencia múltiple a fármacos de serovares de Salmonella fue elevada en las muestras de carne de pollo, con una mayor resistencia observada a la ciprofloxacina. Esto sugiere una posible transmisión horizontal de genes resistentes a quinolonas mediados por plásmidos, lo que podría comprometer el uso clínico de fluoroquinolonas. Por lo tanto, la mejora de la higiene y la provisión de instalaciones adecuadas en los centros de procesamiento de carne podrían ayudar a limitar la contaminación de la carne y la transmisión a través de los alimentos de los serotipos multi resistentes de Salmonella no tifoidea de pollos a humanos.

Palabras clave: Salmonella, resistencia a los antibióticos, carne de pollo, sacrificio, Nigeria 
